\title{
Effect of vegetable and animal protein sources on renal failure in diabetic rats
}

\author{
Nadia Saleh Al-Amoudi \\ Nutrition and Food Department, King Abdul-Aziz University, Jeddah, Saudi Arabia \\ Email address: \\ alamudinadia@gmail.com
}

\section{To cite this article:}

Nadia Saleh Al-Amoudi. Effect of Vegetable and Animal Protein Sources on Renal Failure in Diabetic Rats. International Journal of Nutrition and Food Sciences. Vol. 2, No. 5, 2013, pp. 217-224. doi: 10.11648/j.ijnfs.20130205.11

\begin{abstract}
Objective: This study was carried out to determine the effects of vegetable and animal proteins on renal failure in diabetic rats. Design: We used male, adult Wistar rats $[n=90$ rats $]$ in which diabetic renal disease was induced. Intervention: Rats were fed either a control diet or diets in which the protein came from vegetable [soy, lentil, or white bean] or animal [fish, beef, chicken, or eggs] sources. Main outcome measures: Urinary levels of total lipids, triglycerides, cholesterol fractions, liver enzymes function, total glucose, bilirubin, sodium [Na], potassium $[\mathrm{K}]$, albumin, creatinine and urea nitrogen were determined. Results: The fish protein and white bean protein diets exhibited the best results for lipid profiles in total lipid and triglycerides on renal failure in diabetic rats. Total cholesterol was decreased in the fish and soy protein diets. The serum liver enzyme activities of aspartate and alanine amino transferases showed that all protein sources appeared to perform better than the control group with respect to enzyme activities. However, the fish protein group exhibited the best results. In terms of the effects of the different protein sources on glucose [Glu], the fish protein group exhibited the lowest mean Glu level of all of the groups studied. Moreover, these levels were not significantly different from those of the white bean protein group compared with both control groups. The animal protein groups excreted higher urine volumes and more albumin than the plant protein groups. The creatinine and urea nitrogen levels in the fish protein group were similar to those of the soy group. The white bean protein group exhibited the highest $\mathrm{Na}$ levels among the experimental groups, whereas the egg protein group exhibited the lowest $\mathrm{Na}$ levels. Conclusion: A diet containing low protein fish may slow the progression of chronic renal failure in diabetic rats.
\end{abstract}

Keywords: Rat, Dietary Protein, Diabetes, Nephropathy

\section{Introduction}

Diabetic nephropathy is one of the most devastating complications in patients with diabetes. In diabetic nephropathy, damage to the kidneys occurs as a consequence of hyperglycemia, which induces damage in blood vessels leading to several phenomena, including impaired blood flow. Features of diabetic nephropathy include increased excretion of protein in the urine, increased blood pressure and declining kidney function. Severe diabetic nephropathy can lead to kidney failure and end-stage renal disease (ESRD), during which individuals must rely on hemodialysis, peritoneal dialysis or kidney transplantation to survive. The natural history of diabetic nephropathy includes several stages, starting with apparent normality in the first few years after diagnosis, followed by incipient nephropathy [characterized by the presence of small amounts of protein in the urine, known as microalbuminuria], then by overt clinical nephropathy leading to progressive renal failure [1]

Kidney function is measured as the glomerular filtration rate [GFR], which is a measure of the rate at which blood is filtered by the kidneys. Creatinine clearance measurements are often used as a surrogate for GFR. Once overt nephropathy develops, there is a progressive decline in GFR.This decline can be assessed as an absolute decline in $\mathrm{ml} / \mathrm{min}$ per year. In most patients with diabetic nephropathy, the decrease in GFR approaches linearity and is of the order of 9 to $14 \mathrm{ml} / \mathrm{min} /$ year $[2,3]$.

With regards to progression to ESRD, the prognosis of type 1 diabetes has improved during the past four decades [4]. Initial studies in the $1980 \mathrm{~s}$ demonstrated that approximately $80 \%$ of microalbuminuric type 1 diabetic patients progressed to proteinuria over a period of 6 to 14 years. According to recent studies, only $30-45 \%$ of microalbuminuric patients have been reported to progress 
to proteinuria over 10 years [1]. However, diabetes is still the most important cause of ESRD in industrialized countries [4]. Moreover, nephropathy is a clinical diagnosis based upon the finding of proteinuria in a patient with diabetes and in whom there is no evidence of urinary infection. Conventionally, the level of proteinuria for a diagnosis of 'clinical nephropathy' or 'overt nephropathy' is $0.5 \mathrm{~g} / \mathrm{day}$, which is roughly equivalent to a urinary albumin excretion rate [UAER] of $300 \mathrm{mg} /$ day. Patients with a UAER between 30 and $300 \mathrm{mg}$ /day [or 20 to $200 \mathrm{mg} / \mathrm{L}$ ] are defined as having 'microalbuminuria' or 'incipient nephropathy'. Results in excess of $300 \mathrm{mg} /$ day define clinical and incipient nephropathy. Although timed urine collections remain the 'gold standard' for diagnosis, these are cumbersome to use in routine clinical practice and most definitions of clinical or incipient nephropathy depend upon a 'spot' urine sample and thus a test of albumin concentration. Sensitivity and specificity can be improved by using an early-morning, first-voided specimen and correcting the albumin level for creatinine concentration [albumin: creatinine ratio] [5].

Various nutritional guidelines for the treatment of diabetes have been published over the years [6]. The current U.K. recommendations suggest the amount of protein consumed should not exceed $1 \mathrm{~g} / \mathrm{kg} /$ day [6]. The EURODIAB IDDM Complications Study notes that the average protein intake was $1.5 \pm 0.5 \mathrm{~g} / \mathrm{kg} /$ day [7]. In patients with diabetes and nephropathy, dietary recommendations will change depending on the stage of the disease and treatment modality.

Traditionally low-protein diets (LPD) were rigid and restrictive and required using an exchange system to include both high- and low-biological-value proteins. Low-protein products were available to replace foods such as breads, milk, and biscuits. Many patients described these products as unpalatable and, therefore, unhelpful. The energy, sodium, and potassium intake was assessed with care and monitored for each individual. Compliance with these regimens was difficult and could have required close dietetic monitoring to avoid protein energy malnutrition (PEM). PEM is known to affect outcomes of patients adversely treated by renal replacement therapy [8]. The cause of PEM is often multifactorial and may include a reduced dietary intake and increased nutritional losses.

In the early $1980 \mathrm{~s}$, a number of studies suggested that restriction of dietary protein slowed progression to renal failure $[9,10]$. Most of these studies were on groups of patients with renal failure because of a variety of causes, and findings in the few diabetic patients were not reported separately. More recently, there have been studies only in patients with diabetes. However, protein restriction appears to be little used in routine diabetes care. This may be because of pessimism about compliance; people with diabetes already receive a lot of dietary advice with which compliance is often poor. The lack of use may appear to be justified by the apparently disappointing results from the largest ever trial of protein restriction in renal disease, the
Modification of Diet in Renal Disease (MDRD) study, in which a low-protein diet did not appear to affect the decline in renal function at three years [11]. However, the MDRD study was again of a mixed group [about half of the subjects had glomerulonephritis and polycystic disease, and there were some promising features. Compliance to the LPD was shown to be possible, and a longer follow-up was more promising [12]. Given the variation in response according to the etiology of the renal impairment, recommendation on the use of LPDs in diabetes should be based on trials in patients with diabetes. The aim of this investigation was to study dietary intake from different sources of protein [vegetable and animal] on renal failure in diabetic rats.

\section{Materials and Methods}

\subsection{Materials}

Different protein sources (fish filet, ground beef, chicken breast, lentil, and white bean) were obtained from a local market (Saudia). Other protein sources (soybean and eggs proteins (pure albumin) were purchased from a local market [Cairo, Egypt]. Kits for determination of the outcome parameters were purchased from Sigma-Aldrich (St. Louis, MO, USA) for use in the chemical analysis at King Abdul-Aziz Chemistry Lab, Medical Research Center.

\subsection{Nutritional Experiments}

Male Wistar adult rats [ $n=90$ rats; weight $180-200 \mathrm{~g}$ ] were purchased from Pharmacy College at King Saud University and delivered to the King Fahd Medical Research Center in Jeddah. Animals were housed in individual cages with screen bottoms and fed a basal diet for eight days. The basal diet consisted of $70 \%$ cornstarch, $10 \%$ casein, $10 \%$ corn oil, $4 \%$ salt mixture, $1 \%$ vitamin mixture and $5 \%$ cellulose according to the AOAC guidelines [13].

After feeding on the basal diet for eight days, rats were divided into two groups. The first group ( $n=10$ rats) was fed on the basal diet for another twelve weeks and considered as a negative control [C-ve]. The second group ( $n=80$ rats) was fasted overnight and injected with gentamicin twice per week for two weeks to induce renal failure according to the method described by Farombi and Ekott [14]. The rats were then fed on the basal diet for 48 $\mathrm{h}$, during which time renal failure developed. The second group was fasted overnight and injected with streptozotocin [dissolved in $0.1 \mathrm{M}$ citric acid buffer and adjusted to $\mathrm{pH} 4.5$ ] into the leg muscle [ $5 \mathrm{mg} / 100 \mathrm{~g}$ body weight] to induce diabetes according to Madar [15]. Forty-eight hours after the streptozotocin injection, the second group was divided into eight sub-groups $(n=10$ per group).

Of the eight sub-groups, the first group $(n=10)$ continued to be fed on the basal diet and was considered as a positive control $[\mathrm{C}+\mathrm{ve}]$. The remaining sub-groups $[n$ 
$=10$ per group] were fed fish filet, ground beef, chicken breast, egg protein [pure albumin], soybean, lentil or white bean protein as a substitute for casein.

At the end of experiment, (which lasted for 12 weeks), blood samples were taken from the orbital plexus and centrifuged at $3000 \mathrm{rpm}$ to obtain the sera. The sera and organs were weighed and kept at $-20^{\circ} \mathrm{C}$ until analysis. The levels of serum glucose, total lipids, total cholesterol, and triglycerides were determined according to Tietz [16], Knight et al., [17], Allain et al., [18], and Fossati and Prencipe [19], respectively. High-, low- and very-low-density lipoprotein cholesterol in serum was determined according to Burstein [20], Fruchart [21], and Lee and Nieman [22]. Serum liver enzymes activity [aspartate amino transferase (AST) and alanine amino transferase (ALT), were determined according to Bergmeyer et al. [23]. Albumin, creatinine and urea nitrogen were determined in urine according to Doumas et al. [24], Schirmeister [25], and Patton and Crouch [26]. Sodium $[\mathrm{Na}]$ and potassium $[\mathrm{K}]$ levels in urine were determined calorimetrically according to the method of Henry [27]. Moreover, total bilirubin was assessed using caffeine benzoate to split bilirubin from the unconjugated bilirubin protein complex according to Vinchi et al., [28].

\subsection{Statistical Analysis}

Statistical analysis for the collected data was conducted using analysis of variance (ANOVA) as described in the procedure outlined by Armitage and Berry [29]. The treatment means were compared using the least significant difference test (LSD) at a 5\% level of probability as outlined by Waller and Duncan [30].

\section{Results}

\subsection{Total Lipids, Triglycerides, and Total Cholesterol}

Table [1] indicated all the protein groups exhibited lower levels of all studies parameter compared with the positive control group. The white bean protein group exhibited the lowest mean TL and TG values $[197 \pm 2.65$ and $57 \pm 2.64 \mathrm{mg} / \mathrm{dL}$, respectively]. The soy protein group exhibited the lowest mean TC value $[128 \pm 2.64 \mathrm{mg} / \mathrm{dL}]$, and no significant difference was observed between the soy protein group and the [C-ve] group. The white bean protein group exhibited no significant difference from the [C-ve] group with respect to TL levels, but there was a significant difference between these two groups with respect to TG levels. The fish protein group exhibited the best results among the animal protein groups for all of these parameters. The mean TG value for the fish protein group differed from that of the soy protein group [74 \pm $5.29 ; 80 \pm 5.01 \mathrm{mg} / \mathrm{dL}]$, but this difference did not reach statistical significance. The TC value for the fish protein group was not significantly different from that of the lentil protein group.
Table 1: Effects of the different protein sources on total lipids [TL], triglycerides [TG], and total cholesterol [TC] in diabetic rats modeling renal failure.

\begin{tabular}{llll}
\hline Groups & $\begin{array}{l}\text { Total lipids } \\
\text { mg/dL }\end{array}$ & $\begin{array}{l}\text { Triglycerides } \\
\text { mg/dL }\end{array}$ & $\begin{array}{l}\text { Total cholesterol } \\
\text { mg/dL }\end{array}$ \\
\hline Control -ve & $190 \pm 5.00 \mathrm{~g}$ & $65 \pm 5.00 \mathrm{e}$ & $125 \pm 5.00 \mathrm{e}$ \\
Control +ve & $366 \pm 5.00 \mathrm{a}$ & $131 \pm 7.00 \mathrm{a}$ & $232 \pm 5.00 \mathrm{a}$ \\
Fish protein & $208 \pm 7.00 \mathrm{f}$ & $74 \pm 5.00 \mathrm{~d}$ & $134 \pm 5.00 \mathrm{~d}$ \\
$\begin{array}{l}\text { Meat protein } \\
\text { Chicken }\end{array}$ & $242 \pm 2.00 \mathrm{~d}$ & $97 \pm 2.00 \mathrm{c}$ & $145 \pm 5.00 \mathrm{c}$ \\
protein & $26614.00 \mathrm{c}$ & $124 \pm 5.00 \mathrm{~b}$ & $142 \pm 2.00 \mathrm{c}$ \\
$\begin{array}{l}\text { Egg protein } \\
\text { Soy protein }\end{array}$ & $208 \pm 7.00 \mathrm{~b}$ & $124 \pm 5.00 \mathrm{~b}$ & $184 \pm 5.00 \mathrm{~b}$ \\
$\begin{array}{l}\text { Lentil } \\
\text { protein } \\
\text { White bean } \\
\text { protein }\end{array}$ & $231 \pm 5.00 \mathrm{e}$ & $95 \pm 5.00 \mathrm{c}$ & $136 \pm 5.00 \mathrm{~d}$ \\
\hline
\end{tabular}

\subsection{Serum VLDL, HDL and LDL Levels of Cholesterol}

The results in Table [2] reported the white bean protein group exhibited a lower mean VLDL value $[11.4 \pm 1.58$ $\mathrm{mg} / \mathrm{dL}]$ than did the fish and soy protein groups [14.8 \pm 1.00 and $16 \pm 0.95 \mathrm{mg} / \mathrm{dL}$, respectively]. The groups with the highest VLDL levels were the chicken and egg groups $[24.8 \pm 1.00$ and $24.8 \pm 0.91 \mathrm{mg} / \mathrm{dL}$, respectively]. The egg group exhibited the highest mean HDL value $[105 \pm 1.00$ $\mathrm{mg} / \mathrm{dL}$ ] than all protein sources. The mean LDL values exhibited a different trend; the chicken protein group exhibited the lowest value [14.2 $\pm 0.72 \mathrm{mg} / \mathrm{dL}]$, lower even than the [C-ve] control group. The egg protein group exhibited the highest LDL value of all of the groups studied $[53.2 \pm 2.77 \mathrm{mg} / \mathrm{dL}$

Table 2: Effects of different protein sources on VLDL, HDL and LDL levels in diabetic rats modeling renal failure.

\begin{tabular}{llll}
\hline Groups & VLDL mg/dL & HDL $\mathbf{~ m g} / \mathbf{d L}$ & LDL mg/dL \\
\hline Control-ve & $13 \pm 1.00 \mathrm{f}$ & $95 \pm 5.00 \mathrm{~b}$ & $17 \pm 1.00 \mathrm{~g}$ \\
Control+ve & $26.2 \pm 2.65 \mathrm{a}$ & $82 \pm 2.00 \mathrm{e}$ & $126.8 \pm 2.78 \mathrm{a}$ \\
& $14.8 \pm 1.00 \mathrm{e}$ & $98 \pm 3.00 \mathrm{~b}$ & $21.2 \pm 1.06 \mathrm{f}$ \\
Fish protein & $19.4 \pm 0.90 \mathrm{~d}$ & $85.3 \pm 1.60 \mathrm{~d}$ & $14.3 \pm 0.61 \mathrm{c}$ \\
& & & \\
Meat protein & $24.8 \pm 1.00 \mathrm{e}$ & $85 \pm 1.00 \mathrm{~d}$ & $14.2 \pm 0.72 \mathrm{~h}$ \\
$\begin{array}{l}\text { Chicken } \\
\text { protein }\end{array}$ & $24.8 \pm 0.91 \mathrm{~b}$ & $105.4 \pm 4.68 \mathrm{a}$ & $53.2 \pm 2.77 \mathrm{~b}$ \\
$\begin{array}{l}\text { Egg protein } \\
\text { Soy protein }\end{array}$ & $16 \pm 0.95 \mathrm{~d}$ & $86 \pm 2.00 \mathrm{~d}$ & $26 \pm 1.00 \mathrm{e}$ \\
$\begin{array}{l}\text { Lentil protein } \\
\begin{array}{l}\text { White bean } \\
\text { protein }\end{array}\end{array}$ & $19 \pm 0.98 \mathrm{c}$ & $90.2 \pm 1.71 \mathrm{c}$ & $26.8 \pm 1.58 \mathrm{e}$ \\
\hline
\end{tabular}




\subsection{Serum Liver Enzymes Activities}

Table [3] indicated that all protein sources appeared to perform better than the control group [C+ve] with respect to enzyme activities. Moreover, there were no significant difference between the fish and chicken protein groups with respect to the ALT results $[31 \pm 1.00$ and $32 \pm 1.00 \mathrm{IU} / \mathrm{L}$, respectively]. In addition, there were no differences between the meat, white bean, and soy protein groups $[35.5 \pm 0.90,35.8 \pm 1.58$, and $36 \pm 0.95$, respectively]. No significant differences were observed between the fish protein and chicken protein groups with respect to the AST results; however, there was a significant difference between these groups and the protein groups of eggs and vegetables. Although there was a significant difference between the AST/ALT ratios in the[C+ve] control group and the animal protein groups, the vegetable protein groups' ratios were lower than the ratios of the animal protein groups and were similar to that of the [C-ve] control group.

Table 3: Effects of different protein sources on the ALT and AST liver enzymes and the AST/ALT ratio in diabetic rats modeling renal failure.

\begin{tabular}{llll}
\hline Groups & ALT IU/L & AST IU/L & AST/ALT \\
\hline Control-ve & $20 \pm 10 \mathrm{af}$ & $8 \pm 1.00 \mathrm{~d}$ & $2.5 \pm 0.26 \mathrm{e}$ \\
& $55 \pm 2.00 \mathrm{a}$ & $15 \pm 0.97 \mathrm{a}$ & $3.67 \pm 0.30 \mathrm{a}$ \\
Control +ve & $31 \pm 1.00 \mathrm{e}$ & $9.8 \pm 1.71 \mathrm{c}$ & $3.16 \pm 0.05 \mathrm{c}$ \\
& & & \\
Fish protein & $35.5 \pm 0.90 \mathrm{~d}$ & $10.3 \pm 1.13 \mathrm{c}$ & $3.45 \pm 0.06 \mathrm{~b}$ \\
& & & \\
Meat protein & $32 \pm 1.00 \mathrm{e}$ & $10 \pm 1.00 \mathrm{c}$ & $3.20 \pm 0.10 \mathrm{c}$ \\
& & & \\
Chicken protein & $39 \pm 0.91 \mathrm{~b}$ & $13 \pm 0.99 \mathrm{~b}$ & $3.00 \pm 0.10 \mathrm{c}$ \\
& & & \\
Egg protein & $36 \pm 0.95 \mathrm{~d}$ & $12.5 \pm 1.50 \mathrm{~b}$ & $2.88 \pm 0.11 \mathrm{~d}$ \\
& & & \\
Soy protein & $37.4 \pm 0.98 \mathrm{c}$ & $13 \pm 0.95 \mathrm{~b}$ & $2.88 \pm 0.12 \mathrm{~d}$ \\
& & & \\
Lentil protein & $35.8 \pm 1.58 \mathrm{~d}$ & $12.5 \pm 1.51 \mathrm{~b}$ & $2.86 \pm 0.13 \mathrm{~d}$ \\
$\begin{array}{l}\text { White bean } \\
\text { protein }\end{array}$ & & &
\end{tabular}

\subsection{Serum Glucose and Total Bilirubin}

Table [4] indicates the fish protein group exhibited the lowest mean glucose level $[100.2 \pm 2.43 \mathrm{mg} / \mathrm{dL}]$ of all of the groups studied, but these levels were not significantly different from those of the white bean protein group $[101.0 \pm 1.00 \mathrm{mg} / \mathrm{dL}]$ compared with control group $\mathrm{C}+\mathrm{ve}$, $240.0 \pm 10.0 \mathrm{mg} / \mathrm{dL}$. There were no significant differences between the mean glucose levels of the meat protein [114 \pm $2.00 \mathrm{mg} / \mathrm{dl}]$ and soy or lentil protein groups [114 \pm 2.11 $\mathrm{mg} / \mathrm{dL}$ and $115.4 \pm 5.05 \mathrm{mg} / \mathrm{dL}$, respectively]. With respect to TB levels, the soy and white bean protein groups exhibited better results $[0.38 \pm 0.03 \mathrm{mg} / \mathrm{dL}$ and $0.38 \pm$ $0.02 \mathrm{mg} / \mathrm{dL}$, respectively] than did the rest of the experimental groups. Both of these groups exhibited levels close to that of the negative control group [C-ve], but significantly different from both control groups. The TB levels of the fish protein group were significantly lower than the levels of the positive control group $[0.40 \pm$ $0.03 \mathrm{mg} / \mathrm{dL}$ and $0.70 \pm 0.02 \mathrm{mg} / \mathrm{dL}$, respectively]. The meat protein group did not exhibit TB levels that were significantly different from the fish protein group. All of the experimental protein groups differed significantly from the positive control with respect to TB levels.

Table 4: Effects of different protein sources on glucose and total bilirubin levels [mg/dL] in diabetic rats modeling renal failure.

\begin{tabular}{lll}
\hline Groups & Glucose & Total bilirubin \\
\hline Control -ve & $105 \pm 5.00 \mathrm{e}$ & $0.30 \pm 0.01 \mathrm{~g}$ \\
Control +ve & $240 \pm 10 \mathrm{a}$ & $0.70 \pm 0.02 \mathrm{a}$ \\
Fish protein & $100.2 \pm 2.43 \mathrm{e}$ & $0.40 \pm 0.03 \mathrm{e}$ \\
Meat protein & $114 \pm 2.00 \mathrm{~d}$ & $0.40 \pm 0.02 \mathrm{e}$ \\
Chicken protein & $123 \pm 3.00 \mathrm{c}$ & $0.44 \pm 0.04 \mathrm{~d}$ \\
Egg protein & $131.2 \pm 1.59 \mathrm{~b}$ & $0.46 \pm 0.05 \mathrm{c}$ \\
Soy protein & $114 \pm 2.00 \mathrm{~d}$ & $0.38 \pm 0.03 \mathrm{f}$ \\
Lentil protein & $115.4 \pm 5.05 \mathrm{~d}$ & $0.52 \pm 0.01 \mathrm{~b}$ \\
\hline White bean protein & $101 \pm 1.00 \mathrm{e}$ & $0.38 \pm 0.02 \mathrm{f}$ \\
\hline
\end{tabular}

\subsection{Urinalysis}

From the Table [5] it could be observed the plant protein groups' urine volumes [3.8 to $4.5 \mathrm{~mL} /$ day] were closed to those of the negative control group [3.7 $\mathrm{mL} /$ day]. The urine volumes of the animal protein groups [4.4 to $5.5 \mathrm{~mL} /$ day] were higher than those of the C-ve group [3.7 $\mathrm{mL} /$ day] and lower than those of the $\mathrm{C}+$ ve group [6.7 $\mathrm{mL} / \mathrm{day}]$.

The positive control and fish protein group exhibited the highest Alb. levels while the plant protein groups exhibited lower Alb. levels than did the animal protein groups. There were no significant differences between the chicken protein $[0.02 \pm 0.004 \mathrm{U} / \mathrm{L}]$ and control -ve, or soy protein groups.

From the same table, it was noted that the creatinine and urea nitrogen levels in the fish protein group [116 \pm $4.00 \mathrm{mg} / \mathrm{dL}$ and $2650 \pm 52.00 \mathrm{mg} / \mathrm{dL}$, respectively] were similar to those of the soy protein group $[116 \pm 1.00 \mathrm{mg} / \mathrm{dL}$ and $2650 \pm 63.00 \mathrm{mg} / \mathrm{dL}$, respectively]. Moreover, the chicken, white bean and lentil protein groups' value were no significant difference between these groups for either parameter. 
Table 5: Effects of different protein sources on urine volume and urine albumin, creatinine, and urea nitrogen levels in diabetic rats modeling renal failure.

\begin{tabular}{lllll}
\hline Groups & Urine volume ml/day & Albumin U/L & Creatinine $\mathbf{~ m g / d L}$ & $\begin{array}{l}\text { Urine urea nitrogen } \\
\mathbf{m g} / \mathbf{d L}\end{array}$ \\
\hline Control -ve & $3.7 \pm 0.11 \mathrm{~h}$ & $0.01 \pm 0.001 \mathrm{~g}$ & $94 \pm 3.00 \mathrm{~g}$ & $1650 \pm 50 \mathrm{~g}$ \\
Control +ve & $6.7 \pm 2.23 \mathrm{a}$ & $1.13 \pm 0.003 \mathrm{a}$ & $247 \pm 7.00 \mathrm{a}$ & $8150 \pm 70 \mathrm{a}$ \\
Fish protein & $4.4 \pm 0.10 \mathrm{e}$ & $0.09 \pm 0.001 \mathrm{~b}$ & $116 \pm 4.00 \mathrm{e}$ & $2650 \pm 52 \mathrm{e}$ \\
Meat protein & $4.5 \pm 0.20 \mathrm{~d}$ & $0.08 \pm 0.002 \mathrm{C}$ & $124 \pm 2.00 \mathrm{~d}$ & $3750 \pm 61 \mathrm{~d}$ \\
Chicken protein & $4.9 \pm 0.13 \mathrm{c}$ & $0.02 \pm 0.004 \mathrm{fg}$ & $183 \pm 3.00 \mathrm{c}$ & $6350 \pm 73 \mathrm{c}$ \\
Egg protein & $5.5 \pm 0.26 \mathrm{~b}$ & $0.04 \pm 0.002 \mathrm{e}$ & $97 \pm 2.00 \mathrm{f}$ & $2000 \pm 55 \mathrm{f}$ \\
Soy protein & $4.0 \pm 0.15 \mathrm{f}$ & $0.01 \pm 0.001 \mathrm{~g}$ & $116 \pm 1.00 \mathrm{e}$ & $2650 \pm 63 \mathrm{e}$ \\
Lentil protein & $3.8 \pm 0.19 \mathrm{~g}$ & $0.03 \pm 0.003 \mathrm{f}$ & $183 \pm 2.00 \mathrm{c}$ & $6350 \pm 69 \mathrm{c}$ \\
White bean protein & $4.5 \pm 0.21 \mathrm{~d}$ & $0.05 \pm 0.001 \mathrm{~d}$ & $197 \pm 2.00 \mathrm{~b}$ & $6750 \pm 59 \mathrm{~b}$ \\
\hline
\end{tabular}

\subsection{Urine Na and $K$}

From the Table [6] it could be noticed that the white bean protein group exhibited the highest $\mathrm{Na}$ levels $[319 \pm 3.78$ $\mathrm{mM} / \mathrm{d}$ ] among the experimental groups, whereas the egg protein group exhibited the lowest Na levels $[87 \pm 2.99$ $\mathrm{mM} / \mathrm{d}]$. There were no significant differences between either the fish and soy protein groups or the chicken and lentil protein groups. Moreover, no significant difference was observed between the $\mathrm{Na}$ levels of the egg protein group and those of the C-ve control group. The results for urine $\mathrm{K}$ levels were slightly different from those for sodium.

Table 6: Effects of different protein sources on urine Na and $K$ levels [mM/day] in diabetic rats modeling renal failure.

\begin{tabular}{lll}
\hline Groups & Na mM/day & K mM/day \\
\hline Control -ve & $83 \pm 2.00 \mathrm{f}$ & $24.9 \pm 1.01 \mathrm{~b}$ \\
Control +ve & $350 \pm 5.00 \mathrm{a}$ & $6.7 \pm 0.11 \mathrm{~h}$ \\
Fish protein & $92 \pm 2.00 \mathrm{e}$ & $23.5 \pm 0.50 \mathrm{c}$ \\
Meat protein & $182 \pm 3.00 \mathrm{~d}$ & $21.3 \pm 0.30 \mathrm{e}$ \\
Chicken protein & $220 \pm 4.00 \mathrm{c}$ & $22.3 \pm 0.35 \mathrm{~d}$ \\
Egg protein & $87 \pm 2.00 \mathrm{f}$ & $17 \pm 1.00 \mathrm{~g}$ \\
Soy protein & $92 \pm 2.00 \mathrm{e}$ & $28.7 \pm 0.70 \mathrm{a}$ \\
Lentil protein & $220 \pm 4.00 \mathrm{c}$ & $21.7 \pm 0.20 \mathrm{de}$ \\
White bean protein & $319 \pm 3.00 \mathrm{~b}$ & $18.8 \pm 0.40 \mathrm{f}$ \\
\hline
\end{tabular}

\section{Discussion}

Numerous reports have demonstrated that the nature of dietary protein can influence serum cholesterol concentrations [31, 32]. Experiments performed on animals $[33,34]$ and humans [35] have indicated that plant proteins, particularly soybean protein, tend to exert a hypocholesterolemic effect, whereas animal protein sources, such as casein, tend to be hypercholesterolemic. Furthermore, only in a meta-analysis was the effect of a vegan diet on triacylglycerol levels significant [36, 37]. These findings agree with the present study, which found that plant proteins, especially from soybeans, had hypocholesterolemic effects, whereas casein had hypercholesterolemic effects. However, the animal proteins that were studied, particularly fish protein, exhibited a hypocholesterolemic effect compared with casein. With respect to total lipid and triglyceride levels, fish and soy protein demonstrated the same effects.

In the present study, all of the animal proteins that were examined, except egg protein, lowered LDL largely than did plant proteins. Soy consumption lowers LDL cholesterol levels, although this reduction may only be by a few percentage points $[36,38]$. The fish protein diet performed better than soy protein diet in terms of VLDL, HDL, ALT, AST, serum glucose and $\mathrm{K}$ in the urine, whereas the soy protein diet had better effects on, TC, AST/ALT, TB, Na and $\mathrm{K}$ in the urine than did the fish protein diet.

In the present study, urinary albumin extraction was significant lower in rats fed vegetable protein diets than those fed animal protein diets, except for the chicken protein group. Moreover, results were similar in the soy and lentil protein groups. Previously, it has been reported that vegans have lower urinary albumin excretion than do omnivorous subjects; vegan subjects also consume a smaller quantity of protein $[39,40]$.According to Massey [41], studies have reported that consumption of $0.5 \mathrm{~g} / \mathrm{kg}$ isolated soy protein compared with $0.5 \mathrm{~g} / \mathrm{kg}$ purified casein for four weeks decreased urinary albumin by $9 \%$ in men with type 2 diabetes mellitus and nephropathy [42]. In the present study, soy protein did not reduce urinary albumin when compared with casein, but did decrease this parameter toward normal levels.

Overall, a restricted protein intake does appear to slow the progression of diabetic nephropathy, albeit in a 
non-significant way. The progression rate without treatment has been reported to be a decline in GFR of 9 to 14 $\mathrm{ml} / \mathrm{min} /$ year in type 1 diabetes $[2,3]$. From the result of the meta-analysis, this implies that patients who comply with the low-protein diet can delay dialysis by, on average, around one or two months. Variation among patients also needs to be taken into account. Studies did not give sufficient details to quantify this, but a small average benefit may conceal larger benefits in some people.

Cianciaruso et al., [43] noted that compliance was difficult to achieve, "adherence may be difficult, time consuming and unpleasant for the patients." The problems they listed were: the use of special low-protein foods, the high cost, and the time for separate cooking of meals, palatability, and changes in lifestyle. However, they noted that compliance improved over three years, from about $30 \%$ in year one to about $80 \%$ by the end of year three. This may have been because of the onset of symptoms relieved by LPDs and fear of approaching dialysis. No data on the proportion with diabetes is given. The difficulty of adherence to low-protein restriction should not stop us from giving people with diabetes information on the options. Jibani et al. [44] found that albumin excretion rates fell when patients with microalbuminuria were given a predominantly vegetarian diet, although a sizeable drop in total protein intake from 1.4 to $1.0 \mathrm{~g} / \mathrm{kg}$ /day confounded the results. Pecis et al. [45] compared three diets: a usual diet with $1.4 \mathrm{~g} / \mathrm{kg} / \mathrm{day}$, a LPD with $0.5 \mathrm{~g} / \mathrm{kg} /$ day and a test diet in which chicken and fish replaced red meat. They found that the chicken and fish diets had similar effects on GFR to the LPD, but were much more acceptable. However, this was a short-term study with only three weeks on each diet. They hypothesized that these findings were the result of the much lower levels of glycine, alanine, and arginine in chicken and fish compared to red meat, these being the amino acids with greatest effect on GFR. If such diets are as effective as low-protein ones, then compliance becomes less of an issue. There also might have beneficial effects on cardiovascular risk. Compliance may be improved on a Mediterranean-style diet, characterized by abundant plant foods, fresh fruit, olive oil, dairy products, fish, and poultry consumed in low to moderate amounts and red meat consumed in low amounts. This review included five studies from Italy, three of which provided data on actual protein intake in the LPD group [46, 47]. These studies report good compliance, reporting mean protein intakes of $0.7,0.7$ and $0.9 \mathrm{~g} / \mathrm{kg} /$ day. In this review, only one study found evidence of malnutrition on an intended protein intake of $0.6 \mathrm{~g} / \mathrm{kg} / \mathrm{day}$. It was reported that serum pre-albumin and serum albumin had significantly decreased in the LPD group [46]. In practice, however, the lack of compliance possibly protects against this side effect.

Further long-term research on large representative groups of patients with both type 1 and type 2 diabetes is necessary. In addition, taking into account the variability among patients, there might be a six-month trial in all patients, with continuation only in those who responded best. They think that the top priority should be a trial of usual diet [unrestricted protein] versus reduction to $0.8 \mathrm{~g} / \mathrm{kg} / \mathrm{day}$ [with chicken and fish instead of red meat]. According to their perception, this meal should be compared to a vegetarian diet with no restriction in protein versus a vegetarian diet with modest intake $[1 \mathrm{~g} / \mathrm{kg} / \mathrm{day}]$, with results in terms of progression of diabetic nephropathy and compliance. Outcomes should include all of GFR, quality of life, cost-effectiveness and cardiovascular risk factors such as lipids. There is a research need in fully informed patients to assess whether dialysis can be postponed for worthwhile periods, even if only in some patients, without undue reduction in quality of life because of dietary restriction [48].

Based on 12 studies, including from eight to 160 people with type 1 and type 2 diabetes for at least an average four-month period, restricted protein intake appeared to slow progression of diabetic kidney disease, but not by a significant degree. However, individual variation existed; therefore, a low-protein diet may benefit some individuals. A low-protein diet can be difficult to follow, especially over the long term. Reducing the amount of animal protein is the usual method, but some evidence suggests that a shift from red meat to white meat and fish or vegetables may give similar results. We found no data on the effects of a low-protein diet on health-related quality of life and costs [49].

Therefore, Diabetic patients with chronic renal failure should be advised to go on protein restriction. This loss in calories should not be compensated by fat calories, but by an increase in the amounts of ingested carbohydrates alone. This increase may even exert a beneficial effect on the patient's diabetes. The management of such patients calls for close collaboration between the diabetologist and the nephrologist [50].

Bilirubin is one of the degradation products of hemoglobin formed when red blood cells die. Bilirubin exists in the insoluble unconjugated form [also indirect bilirubin], or soluble glucuronide conjugated form [also direct bilirubin]. Conjugated bilirubin moves into the bile canaliculi of the liver and then to the gall bladder. When stimulated by eating, bile [including the conjugated bilirubin] is excreted into the small intestine, where bilirubin is converted into urobilinogen. Bilirubin is a key diagnostic indicator. High levels of bilirubin result when too much hemoglobin is broken down, or the removal of bilirubin does not function properly. The accumulation of bilirubin in the body causes jaundice [51].

This study concluded that a low-protein fish diet may have slowed down the progression of chronic renal failure in diabetic rats to a greater degree than did the other studied diets.

\section{Competing interests}

The author declare that I have no competing interests 


\section{Acknowledgments}

The author wish to thank Professor Mansour Soliman and Professor Taha Qumusani the Manager and the Vice Manager of King Fahad Medical Research Center for their help and support. The author would like to thank Alaa Babaeer,Alaa kabbarah,Omar Alkhattab ,Osama Alsulimani ,Fadl Jamjoom, Ahmed Altowaireb, Loai Altaib,Mowaffak Showsh,Saleh Bamunif,Amr Eid and Abdullah Bokhary for their help in the experimental work.

\section{References}

[1] Gross JL, de Azevedo MJ, Silveiro SP, Canani LH, Caramori ML, Zelmanovitz T. Diabetic Nephropathy: Diagnosis, Prevention, and Treatment. Diabetes Care. 2005; 28:164-176.

[2] Parving HH, Smidt UM, Friisberg B, Bonnevie-Nielsen V, Andersen AR. A prospective study of glomerular filtration rate and arterial blood pressure in insulin-dependent diabetics with diabetic nephropathy. Diabetologia. 1981; 20:457-461.

[3] Viberti GC, Bilous RW, Mackintosh D, Keen H. Monitoring Glomerular Function in Diabetic Nephropathy. The Am J Med. 1983;74:256-264.

[4] Finne P, Reunanen A, Stenman S, Groop PH, Gronhagen-Riska C. Incidence of end-stage renal disease in patients with type 1 diabetes. JAMA 2005; 295:1782-1787.

[5] Bilous RW. The kidney in systemic disease. In: Warrell DA, Cox TM, Firth JD, Benz EJ, eds. Oxford Textbook of Medicine. Oxford: Oxford University Press; 2005.

[6] Connor H, Annan F, Bunn E, Forst G, McGough N, Sarwar $\mathrm{T}$, Thomas B. The implementation of nutrition advice for people with diabetes. Diabet. Med. 2003; 20:789-807.

[7] Toeller M, Klischan A, Heitkamp G, Schumacher W, Milne R, Buyken A, Karamanos B, Gries FA. Nutritional intake of 2868 IDDM patients from 30 centers in Europe. Diabetologia. 1996; 39:929-939.

[8] Ikizler TA, Greene JH, Wingard RL. [1995].Spontaneous dietary protein intake during progression of chronic renal failure. Am J Nephrol. 1995;6:1386-1391.

[9] El Nahas AM, Masters-Thomas A, Brady SA. Selective effect of low protein diets in chronic renal diseases. Brit Med J. 1984;289:1337-1341.

[10] Rosman JB, Meijer S, Sluiter WJ, Wee PMT, Piers-Becht TPM, Donker AJM. Prospective randomised trial of early protein restriction in chronic renal failure. Lancet; December. 1984;1291-1296.

[11] Klahr S, Levey AS, Beck GJ. The effects of dietary protein restriction and blood pressure control on the progression of chronic renal diseases. New Eng J Med. 1994;330:884.

[12] Levey AS, Beck GJ, Caggiula AW. Trends towards a beneficial effect of a low protein diet during additional follow-up in the Modification of Diet in Renal Disease Study. Am J Nephrol. 1994; 5:336A.

[13] AOAC. Official Methods of Analysis of the Association of
Official Analytical Chemists, 18th ed., Washington, DC, 2005.

[14] Farombi OE, Ekott M. Cureuminatteruates gentamicin induced renal oxidative damage in rats. Food and Chemical Toxicology, 2006; 44:1443-1448.

[15] Madar Z. Effect of brown rice and soybean dietary fiber on the control, glucose, and lipid metabolism in diabetic rats. Am Med J Clin Nutr. 1983; 388-393.

[16] Tietz NW. Text Book of Clinical Chemistry. P.796.Saunders, WB. Co., London-Philadelphia; 1986.

[17] Knight JA, Anderson S, and James MR. Chemical basis of the sulfophospho vanillin reaction for estimating total serum lipids. Clin Chem. 1972; 18[3]: 199-202.

[18] Allain CC, Poor LS, Chan SO. Enzymatic determination of total serum cholesterol. Clin Chem. 1974; 20[4]:470-475.

[19] Fossati P, Prencipe L. The determination of triglyceride using enzymatic methods. Clin Chem. 1982; 28:2077-2081.

[20] Burstein M. HDL Cholesterol determination after separation of high density lipoprotein. Lipids Res. 1970; 11:583-589.

[21] Fruchart JC. LDL Cholesterol determination after separation of low density lipoprotein. Rev Fr Des Laboratory. 1982; 103:7-17.

[22] Lee R, Nieman D. Nutritional Assessment. 2nd Edition. Mosby, Missouri, USA; 1996.

[23] Bergmeyer HU, Horder M, Rej R. Approved recommendation on IFCC method for the measurement of catalytic concentration of enzyme. Part 2. J Clin Chem. 1985; 24[7]:497-510.

[24] Doumas BT, Watson WA, Biggs HG. Albumin standard and measurement of serum albumin with bromocresol green. Clin Chem. 1971; 31:87-92.

[25] Schirmeister J. Creatinine standard and measurement of serum creatinine with picric acid Dtsch Med Wschr. 1964; 89:1018-1022.

[26] Patton CH, Crouch SR. Enzymatic colorimetric method to determine urea in serum. Anal Chem. 1977; 49:464-469.

[27] Henry RJ. Clinical Chemist. Principles and Techniques, 2nd Edition, Hagerstown [MD], Hareer, Row. 1974; PP: 882.

[28] Vinchi F, Gastaldi S, Silengo L, Altruda F, Tolosano E. Hemopexin prevents endothelial damage and liver congestion in a mouse model of heme overload. Am J Pathol. 2008; 173[1]: 289-299.

[29] Armitage P, Berry G. Statistical Method in Medical Research. Blackwell, Oxford, UK, 1987; PP: 93-213.

[30] Waller WM, Duncan DB. A bays role for symmetric multiple composition problem. Am Sate Assoc J. 1969; 65:1485-1492.

[31] Giboney MJ, Kritchevsky D. Animal, and Vegetable Proteins in Lipid Metabolism and Atherosclerosis. Current Topics in Nut \& Dis Vol 8, PP: 177. New York, Alan R. Liss Inc; 1983.

[32] Lovati MR, West C, Sirtori C, Beynen A. [1990]. Dietary animal proteins and cholesterol metabolism in rabbits Brit $\mathrm{J}$ 
Nutr. 1990; 64:473-485.

[33] Carroll KK.[1978]. The role of dietary protein in hypercholesterolemia and atherosclerosis. Lipids. 1978; $13: 360-365$

[34] Kyuyvenhoven MW, West CE, Vander Meer R, Beynen AC. Fecal steroid excretion in relation to the development of casein-induced hypercholesterolemia in rabbit. J Nutr. 1986; 116:1395-1404.

[35] Sirtori CR, Agradi F, Mantero O, Conti F, Gatti E. Soy bean protein diet in the treatment of type II hyperlipoproteinaémia. Lancet. 1977; I: 275-277.

[36] Anderson JW, Johnstone BM, Cook-Newell ME. Meta-analysis of the effects of soy protein intake on serum lipids. N Engl J Med. 1995; 333:276-282.

[37] Jenkins DJ, Kendall CW, Vidgen E. High-protein diets in hyperlipidemia: Effect of wheat gluten on serum lipids, uric acid, and renal function. Am J Clin Nutr. 2001; 74:57-63.

[38] Sacks F, Lichtenstein A, Van Horm H, Harris W, Kris-Etherton P, Winston M. Soy protein, isoflavones and cardiovascular health: An American Heart Association Science Advisory for Professionals from the Nutrition Committee. Circulation, 2006; 113:1034-1044.

[39] Margetts BM, Beilin LJ, Vandongen R, Armstrong BK. Vegetarian diet in mild hypertension: A randomized controlled trial. Br J Med. 1986; 293:1468-1471.

[40] Wiseman MJ, Hunt R, Goodwin A, Gross JL, Keen H, Viberti DC. Dietary composition and renal function in healthy subject. Nephron. 1987; 46:37-42.

[41] Massey L. Vegetarian diet may not be better- Renal and Urology News available at http://www.renalandurologynews.com. 2007.

[42] Teixeria SR, Tappenden KA, Carson L, Jpnes R, Parbhudesai M, William P, Erdman JW. Isolated soy protein consumption reduces urinary albumin excretion and improves the serum lipid profile in men with type 2 diabetes mellitus and nephropathy. J Nutr. 2004; 134:1874-1880.
[43] Cianciaruso B, Capuano AD, Amaro E, Ferrara N, Nastasi A, Conte G, Bellizzi V, Andreucci VE. Dietary compliance to a low protein and phosphate diet in patients with chronic renal failure. Kidney International. 1989; 36:173-176.

[44] Jibani MM, Bloodworth LL, Foden E, Griffiths KD, Galpin OP. Predominantly vegetarian diet in patinets with incipient and early clinical diabetic nephropathy: effects on albumin excretion rate and nutritional status. Diab Med. 1991; 8:949-953.

[45] Pecis M, de Azevedo MJ, Gross JL. Chicken and fish diet reduced glomerular hyperfiltration in IDDM patients. Diabetes Care. 1994; 17:665-72.

[46] Meloni C, Morosetti M, Suraci C, Pennafina MG, Tozzo C, Taccone-Gallucci M, Casciani CU.[2002]. Severe dietary protein restriction in overt diabetic nephropathy: benefits or risks?. J Ren Nutr. 2002; 12:96-101.

[47] Meloni C, Tatangelo P, Cipriani S, Rossi V, Suraci C, Tozzo C, Rossini B, Cecilia A, Di Franco D, Straccialano E, Casciani CU. Adequate protein dietary restriction in diabetic and nondiabetic patients with chronic renal failure. J Ren Nutr. 2004; 14:208-213

[48] Raine AEG. The rising tide of diabetic nephropathy - the warning before the flood? Nephrology Dialysis and Transplantation. 1995; 10:460-461.

[49] Robertson LM, Waugh N, Robertson A. Protein restriction for diabetic renal disease. Cochrane Database of Systematic Reviews, Issue 4. Art. No.: CD002181. DOI: 10.1002/14651858.CD002181.pub2. 2007.

[50] Gin H, Rigalleau V, Aparicio M. Which diet for diabetic patients with chronic renal failure?. Nephrol Dial Transplant. 1999; 14[11]: 2577-2579 .

[51] Nedredal GI, Amiot BP, Nyberg P, Luebke-Wheeler J, Lillequard JB, Mckenzie JJ, Nyberg SL. Optimization of mass transfer for toxin removal and immunoprotection of hepatocytes in a bioartificial liver. Biotechnol Bioeng. 2009; 104[5]:995-1003. 